\title{
Patent Applications for Electronic Publishing Market (2014-2018). Selected Issues
}

\author{
Adam Jachimczyk \\ ORCID 0000-0003-2917-6926 \\ Department of Bibliography and Documentation, \\ Faculty of Journalism, Information and Book Studies, \\ University of Warsaw
}

\begin{abstract}
Purpose/Thesis: The article analyses patent applications for inventions in the area of electronic publishing. Its investigates how the number of patent applications changed in the years 2014-2018, which companies were the most active in the field, and what was their providence. The issues of crucial importance to the inventors were identified by the study of the symbols used by International Patent Classification.

Approach/Methods: The analysis was based on the data from the base Lens.org from years 2014-2018. In total, 1733 patent applications related to electronic publishing were identified.

Results and conclusions: The study recorded an increasing activity of Chinese and Korean inventors, and a low number of patent applications filed by European firms. The applicants focus on specific functions facilitating interaction between the user and digital devices; a relatively high number of applications is concerned with electronic commerce, and with the use of electronic publishing in education. Originality/Value: An analysis of patent applications may help to identify specific phenomena occurring in the field of information technologies. It records the recent trends in research, and identifies the countries and agents which lead the development of widely understood electronic publishing.
\end{abstract}

Keywords

Ebooks. Electronic books. e-Publications. Patents.

Received: 18 October 2019. Reviewed: 24 November 2019. Accepted: 10 December 2019.

\section{Introduction}

Electronic publishing (e-publishing) refers to publications of different types (books, press, journals, websites) available in many formats (HTML, EPUP, MOBI, PDF) on various devices (designated reading devices, or less specialized devices, such as personal computers, tablets, or smartphones) (Burke, 2013).

The emergence of portable devices (e.g. Sony Data Discman, or NuvoMedia's Rocket) in the 1990s constituted a significant development for the devices enabling access to electronic publishing. Because of their limitations (small screens, low resolution, limited memory), they were not popular with the users (Herther, 2008).

In the first decade of the 21st century, the spread of electronic paper produced by E Ink company inspired further development of the electronic publishing market and the devices facilitating access to it. By the end of the first decade, at least $90 \%$ of the producers of 
e-readers used the electronic paper (Harris, 2010). Furthermore, many models of e-readers entered the market. In 2010 alone, the produces introduced 15 new devices (Manley \& Holley, 2012).

Another factor which contributed to the growth of e-publishing was the appearance of devices (mobile phones and slightly larger devices, so-called tablets) with touch-screens, which became an alternative to the reading devices with e-ink screens, as they supported multimedia content and made it possible to handle richly illustrated publications. With the development of these devices, bookstores started to sell more digital publications, while the publishers gradually resigned from burdensome security technologies, which restricted the use of e-publications, e.g. by restricting the number of devices on which a purchased copy could be read.

E-publications have been on the offer of big- and small-scale publishers for several years now. Although the sales remain small in comparison to those of the print books, they have been increasing in the recent years. Only in the last years the growth became slightly slower (Milliot, 2018; Springer, 2017).

\section{The methods of the analysis of patent claims}

According to the definition published by the Patent Office of the Republic of Poland (UPRP), a patent is "...the exclusive right to use the invention for a specified period, for profit (industrial, commercial) in the territory of a State or States, granted by the competent authority of the state, regional or international" (UPRP, n.d.-a). The exclusive right to a given invention ensures that the author is protected from unfair competition from other agents wishing to use the technological solution in their products. It also creates opportunities for extra profits from selling, or licensing the patent to be used by other agents (Redl et al., 2016).

The process of acquiring a protected status for the invention is relatively long. It starts with filing an application in the appropriate intellectual property office. The period between filing the application and the moment it is published might be longer than ten months (in Poland, this process takes between 12 and 18 months) (Redl et al., 2016; Śnieżko, n.d.; UPRP, n.d.-c). The decision regarding the patent itself might be made within years of filing the application (Nauka w Polsce, n.d.). We should bear in mind that some of the declared and patented solutions will never be employed, e.g. because of the limited possibility of industrial use (Burak, 2015).

The general availability of sources of information on patents, such as the databases of national intellectual property offices, the Espacenet (European Patent Office), or Patentscope (World Intellectual Property Organization) allows for a comprehensive analysis of patent applications. The research is concerned with, e.g., the extent of technological innovation in specific countries (Hicks et al., 2001; Nikzad, 2014; Meyer et al., 2003), in specific organizations (Kang, 2015; Martínez \& Rama, 2012), or generally, in a given field (Jana et al., 2012; Vandeberg \& Boon, 2009). The researchers also analyze patent applications to identify technologies to be developed in the future (Daim et al., 2006; Trappey et al., 2011). Patent analysis is also commonly used in the so-called competitive intelligence. The study of patent applications allows to determine the quality and to identify the assets of other companies, in order to carry out a fusion or an acquisition, or to identify the persons which 
play the key role in the development sector of these companies (Breitzman \& Mogee, 2002; Breitzman \& Thomas, 2002).

The researchers employ various methods to analyze the patent applications. The most basic method comprises quantitative analysis of the meta data contained in the file (the country where the application was filed, the date the application was filed, last name of the applicant, the date the application was published, the date the patent was granted, the symbol of type classification). The researchers combine it with an analysis of abstracts or full texts of the patent files to identify the nature of a given technical solution (Abraham \& Moitra, 2001; Singh et al., 2018).

The researchers also seek to identify the most relevant data set for the analysis. Basing on the patent applications in the automotive sector, Xie and Miyazaki (2013) established that browsing the databases with the use of keywords included in the title of the patent application, the abstract, and the patent claim, yields the best results. International Patent Classification (IPC) may also be used to identify the patent applications in a given sector (Abraham \& Moitra, 2001). The symbols of IPC may also be correlated with other data. In their study of Apple's technological innovation, Jun and Sung Park (2013) correlated the ICP symbol with the year of the patent application to identify the issues which in the recent years have been most important for the company.

We should also mention the studies which analyze the references to other patents in applications, e.g. in order to trace the technological development in a given sector (Gui et al., 2019), and those which record the references to websites of specific organizations as an indicator of their technological level (Orduna-Malea et al., 2017). The researchers use the techniques of text mining, information visualization, or natural language processing to analyze the unstructured data contained in the abstract, the patent claim, or the description of the invention (Abbas et al., 2014).

\section{Objectives and methods}

The e-publishing market should be considered from the point of view of technological infrastructure (hardware and software) which enables the user to access the digital content. Patent applications filed at the appropriate intellectual property office may serve as an indicator of technological development, and as a measure of innovation.

For this purpose, the patent applications from years 2014-2018 were reviewed. This period was chosen to allow tracking specific phenomena related to the development of technology connected with e-publishing, which occurred in an already formed market where a relatively high number of publishers as well as producers of devices and software enabling the access to the digital content were already operating. The goals of the analysis were:

(1) to identify the countries where the highest numbers of patent applications come from;

(2) to establish the agents who filed the highest numbers of applications and were granted the highest number of grants, and the time at which they made the applications;

(3) to establish the thematic scope of the patent applications.

A quantitative analysis was based on the select metadata describing the patent applications: the date the application was filed, the title of the claim, the name of the applicant, 
the type of the application (an application, a granted patent), the number of priority, the ICP symbol.

The subject of the applications was established with a reference to the ICP symbols. All symbols used to characterize the matter of the applications were identified. The qualities of the inventions were identified basing on the frequency with which certain ICP symbols occurred in the description. The subject analysis of applications was supplemented by the examples of claims concerned with the issues specific to different groups distinguished by ICP.

\subsection{The selection of research data}

The data was collected from the base Lens.org, which was developed as a result of a collaboration between an Australian non-profit organization Cambia and Queensland University of Technology. The database collects the data on patent applications from European Patent Office, United States Patent and Trademark Office, World Intellectual Property Organization and Intellectual Property Australia. The dataset comprises c. 120 millions of records from 65 jurisdictions registering the filed patent applications (per data from October 31st, 2019) (Lens, n.d.). The website also publishes a set of tools for the analysis of the found patent claims.

The data for the analysis were collected on November 19th, 2019. To find patent applications, the following command was used. Following the results of the study conducted by Xie and Miyazaki (2013), keywords were used as search terms to browse patent names, abstracts, and claims, as applicants should state technical qualities of the invention, or describe its application in the patent claim (UPRP, n.d.-b).

title:(Ebook" OR "e-book" OR "digital book" OR ereader" OR epub OR "electronic books" OR "electronic publication" OR "electronic publications" OR "e-reader" OR "electronic book") OR abstract:(Ebook" OR "e-book" OR "digital book" OR ereader* OR epub OR "electronic books" OR "electronic publication" OR "electronic publications" OR "e-reader" OR "electronic book") OR full_text:(Ebook" OR "e-book" OR "digital book" OR ereader" OR epub OR "electronic books" OR "electronic publication" OR "electronic publications" OR "e-reader" OR "electronic book") OR claims:(Ebook" OR "e-book" OR "digital book" OR ereader" OR epub OR "electronic books" OR "electronic publication" OR "electronic publications" OR "e-reader" OR "electronic book")

The use of keywords as search terms, rather than ICP classification, to identify patent applications seems more justified, especially in a study on constantly developing technologies which are not assigned a strictly defined category in the abovementioned system (Xie \& Miyazaki, 2013). The extensive search query was used to identify the largest possible set of files related to the widely understood area of e-publishing. It was not an infallible method. Lack of control over the terminology of the applications was an obstacle to precise browsing of very large sets of patent files. Montecchi et al. (2013) noted following problems in the descriptions of patents:

- the varying degree of detail, depending on the specific style of the author of the description and the application of different terms to refer to one issue. In the case of e-publishing, the variations included ereaders and e-readers, ebook and e-book;

- imprecise, incorrect terminology; occasionally new coinages used to describe the claimed inventions; lack of a standardized terminology for the new technologies; 
- the use of automated translation, which might disrupt the meaning of the original text.

The search results were narrowed down to patent applications filed between 2014 and 2018. In total, the set comprised 3721 records. The duplicated descriptions of the files, filed at different intellectual property offices, were eliminated. When a duplicate was identified, the earliest record was preserved. The descriptions of patents which did not relate to the search command were eliminated as well. In the end, 1733 records remained as the subject of the following analysis.

The names of applicants, recorded differently in different files (e.g. Google was referred to as Google INC and Google LLC), were standardized for the purposes of the study. Furthermore, if it was established that two agents were related, the patent was assigned to the mother company. This was the case with Audible, which is a subsidiary of the Amazon corporation. The tables below employ the phrasing used in the application. In the case of the Kobo company, all applications where it was identified as the applicant, were assigned to its current iteration, Rakuten Kobo Inc., as it has been referred to since the Canadian producer was acquired by the Japanese corporation Rakuten.

The analysis had certain limitations. Because the search command was formulated in English, the applications in other languages were not taken into account. Other limitations derived from the problems discussed above, i.e. the imprecise terminology, or an incorrect choice of keywords used to browse the data bases. Furthermore, the analysis did not account for the applications which related to e-publishing, but did not include any of the abovementioned key words in the title, the abstract, or the patent claim.

\section{Results}

Within the studied period, the average of 350 applications per year was filed. Only in 2014 and in 2015 did this number reach above the average. The deviation in 2018 should be seen as a result of the time spent between the moment an application is filed and the moment it is published, as the regular period of upwards of ten months has not yet passed (Fig. 1).

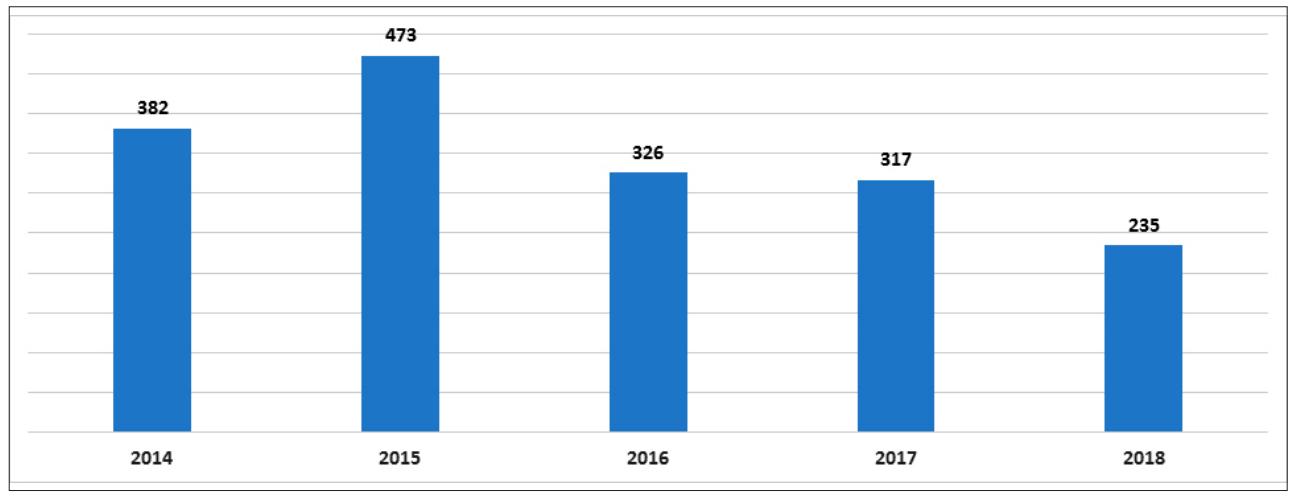

Fig. 1. The number of patent applications per year in the years 2014-2018 


\subsection{The providence of the application}

The providence of the application might be identified in the base Lens.org, which designates it as the priority number, assigned in the moment of filing the application (Espacenet, n.d.). However, it is not a perfectly precise information, as agents might file applications in various countries (Tab 1$)$.

Tab. 1. Countries, where (more than 10) patent applications were file

\begin{tabular}{|l|c|c|}
\hline \multicolumn{1}{|c|}{ Providence } & Number of applications & \% (n=1733) \\
\hline China & 773 & 44.60 \\
\hline United States & 502 & 28.97 \\
\hline South Korea & 193 & 11.14 \\
\hline Japan & 118 & 6.81 \\
\hline Taiwan & 53 & 3.06 \\
\hline Great Britain & 23 & 1.33 \\
\hline $\begin{array}{l}\text { European Patent } \\
\text { Office* }\end{array}$ & 16 & 0.92 \\
\hline India & 14 & 0.81 \\
\hline
\end{tabular}

"The number of applications filed at the European Patent Office.

For the sake of comparison, a list of 43 agents which filed at least five applications in the period studied has been prepared, with a consideration for their country of origin (Tab. 2).

Tab. 2. The country of origin of the agents with the highest number of patent applications

\begin{tabular}{|l|c|c|}
\hline \multicolumn{1}{|c|}{ Country } & Number of agents & \% $(\mathbf{n}=\mathbf{4 3 )}$ \\
\hline China & 19 & 44.19 \\
\hline United States & 10 & 23.26 \\
\hline Japan & 7 & 16.28 \\
\hline South Korea & 4 & 9.30 \\
\hline France & 1 & 2.33 \\
\hline Netherlands & 1 & 2.33 \\
\hline Taiwan & 1 & 2.33 \\
\hline
\end{tabular}

In the case of China, South Korea and Taiwan, the results were similar. The variations observed in the case of Japan and USA might be explained with a reference to the number of the agents filing the applications. In USA, there probably has been a higher number of agents, who filed less than five applications; the opposite was the case in Japan, where a higher number of agents filed more than five applications.

Inevitably, Tables 1 and 2 do not record the activity of corporations operating on the international scale, which often acquire companies operating in other countries and become 
the owners of their patents. Rakuten Kobo Inc. might serve as an example, as it was established as a result of an acquisition of a Canadian producer of e-book readers by Japanese corporation Rakuten (BBC, 2011).

The analysis of data shows the countries, which begin to dominate the discussed field. These are China, which is the country of origin for almost $45 \%$ patent applications, United States, South Korea, Japan, and Taiwan. In this technological race, Europe is visibly losing distance, as only a relatively small number of applications comes from its countries. The countries featured in the Table 1 are the source of almost $98 \%$ of the applications filed in the period discussed.

\subsection{Applicants}

In total, 1013 entities (companies and private persons) that filed a patent application were identified. This set includes 797 entities which filed only one application. 199 entities filed between two and nine applications. Numerous applications were jointly filed by more than one entity, e.g. Univ Peking Founder Group Co. and Beijing Founder Electronics Co., Ltd filed 17 joint applications.

Tab. 3. The most active entities (who filed more than 10 applications)

\begin{tabular}{|l|c|c|}
\hline \multicolumn{1}{|c|}{ Entity } & Number of applications & Number of patents \\
\hline Rakuten Kobo Inc. & 103 & 16 \\
\hline IReader Tech Co., Ltd & 99 & 51 \\
\hline Amazon Tech Inc. & 65 & 64 \\
\hline Samsung Electronics Co., Ltd & 29 & 12 \\
\hline IBM & 28 & 18 \\
\hline Alibaba Group Holding Ltd & 22 & 2 \\
\hline China Mobile Comm Corp & 18 & 1 \\
\hline Univ Peking Founder Group Co. & 17 & 5 \\
\hline Beijing Founder Electronics Co., Ltd & 17 & 4 \\
\hline Microsoft Corp & 16 & 6 \\
\hline Dainippon Printing Co., Ltd & 16 & 5 \\
\hline Beijing Xiaomi Technology Co. & 16 & 8 \\
\hline Google LLC & 15 & 4 \\
\hline Beijing Qihoo Tech Co., Ltd & 14 & 4 \\
\hline Tencent Tech (Beijing) Company Ltd & 12 & 4 \\
\hline Beijing Jingdong Century Trading Co., & 12 & 1 \\
\hline Ltd & 10 & \\
\hline Woongjin Thinkbig Co., Ltd & & 40 \\
\hline
\end{tabular}

Rakuten Kobo dominates the number of applications (Tab. 3). In the last five years, Chinese company IReader has also begun to show an increased activity in filing the patent applications. Amazon, which recently reached dominance over the e-publishing market, 
especially in the United States, filed slightly less applications. Amazon's advantages are the introduction of innovative hardware solutions, e.g. the Kindle reader, whose first iteration entered the market in 2007, and a wide offer of digital publications which might be accessed with this device. The group featured in Table 3 also includes the leaders of the IT market, Alibaba, Google, IBM, Microsoft, and Samsung, among others.

It should be mentioned that Sony and the bookstore chain Barnes \& Noble filed a relatively low number of applications (11 in total). Even in the beginning of the second decade of the 21st century, these companies were trying to match Amazon, and to introduce their own e-readers onto the market, e.g. the Nook reader of Barnes \& Noble (Griffey, 2012). Other IT giants (Apple, Lenovo), filed 13 applications in the period under discussion.

The situation looks slightly different if we consider the number of patents granted. Almost $27 \%$ of the applicants considered received the patent they applied for. Here, Amazon dominates with exclusive rights to 64 inventions. IReader boasts a slightly lower number (51) of rights. Together, Amazon, IReader, and Rakuten Kobo have rights to almost 29\% of the inventions.

Tab. 4. The number of patent applications filed by the most active entities in years 2014-2018

\begin{tabular}{|l|c|c|c|c|c|c|}
\hline \multicolumn{1}{|c|}{ Entity } & $\mathbf{2 0 1 4}$ & $\mathbf{2 0 1 5}$ & $\mathbf{2 0 1 6}$ & $\mathbf{2 0 1 7}$ & $\mathbf{2 0 1 8}$ & Total \\
\hline Rakuten Kobo Inc. & 67 & 35 & - & - & 1 & 103 \\
\hline IReader Tech Co., Ltd & - & 1 & 8 & 35 & 55 & 99 \\
\hline Amazon Tech Inc. & 30 & 28 & 6 & 1 & - & 65 \\
\hline Samsung Electronics Co., Ltd & 4 & 20 & 4 & 1 & - & 29 \\
\hline IBM & 5 & 10 & 7 & 6 & - & 28 \\
\hline Alibaba Group Holding Ltd & 2 & 1 & 5 & 10 & 4 & 22 \\
\hline China Mobile Comm Corp & - & - & 1 & 2 & 15 & 18 \\
\hline Univ Peking Founder Group Co. & 5 & 4 & 3 & 5 & - & 17 \\
\hline Beijing Founder Electronics Co., Ltd & 6 & 2 & 1 & 7 & - & 16 \\
\hline Microsoft Corp & 4 & 7 & 3 & 2 & - & 16 \\
\hline Beijing Xiaomi Technology Co. & 9 & 2 & 4 & 1 & - & 16 \\
\hline Dainippon Printing Co., Ltd & 10 & 3 & 1 & 1 & - & 15 \\
\hline Google Inc & - & 14 & - & - & - & 14 \\
\hline Beijing Qihoo Tech Co., Ltd & 2 & 4 & 3 & 2 & 1 & 12 \\
\hline Tencent Tech (Beijing) Co., Ltd & - & 2 & 9 & 1 & - & 12 \\
\hline Beijing Jingdong Century Trading Co., Ltd & 5 & 4 & 1 & - & - & 10 \\
\hline Woongjin Thinkbig Co., Ltd & & & &
\end{tabular}

Amazon, IReader, Alibaba and Tencent, among others, filed the applications most regularly. Table 4 shows that in 2018, Amazon filed no applications. Between 2016 and 2018, Rakuten Kobo filed only one application, as did Google. However, we should not assume that these companies became significantly less active. The unusual activity of IReader is striking: 90\% of their applications were filed between 2017 and 2018. 


\subsection{Subject of the applications}

The analysis of the thematic scope of the patent applications was based on the IPC symbols attached to the description. A complete IPC symbol is made up of a symbols denoting section, class, subclass, group, and subgroup (UPRP, 2012). For example, GO6Q 30/02 represents a file assigned to section G (Physics), class 06 (Computing; calculating; counting), subclass $Q$ (Data processing systems or methods, specially adapted for administrative, commercial, financial, managerial, supervisory or forecasting purposes; systems or methods specially adapted for administrative, commercial, financial, managerial, supervisory or forecasting purposes, not otherwise provided for); subgroup 30/02 (Marketing, e.g. market research and analysis, surveying, promotions, advertising, buyer profiling, customer management or rewards; Price estimation or determination).

The table includes every symbol which featured at least 50 times. It is not a perfect indicator of the thematic scope of the application because of the superficiality of some descriptions. Less than 6\% of the descriptions used only one symbol, G06F17/20 (now reclassified as G06F16/00-G06F16/958), which gives only a general indication of the thematic scope of the application (Information retrieval; Database structures therefor; File system structures therefor - Organization or management of web site content, e.g. publishing, maintaining pages or automatic linking). Only one ICP symbol was used to describe almost 33\% files; only $1 \%$ were not assigned any symbols.

More elaborate symbols are slightly more informative. Numerous applications were put in the subgroup G06F3/048 (Interaction techniques based on graphic user interfaces [GUI], which "covers subject matter where the focus is placed on the way the user can interact with the displayed data") (IPC Publication, n.d.). This group includes descriptions of 490 files with symbols G06F3/0481, G06F3/0483, G06F3/0484, G06F3/0488.

These are the applications concerned with, e.g. browsing websites in digital publications proposed by Rakuten Kobo (Parker \& Landau, 2016), IReader (Chen et al., 2018) or Google Beavers et al., 2016). The group also includes a project designed by Rakuten Kobo, enabling a display of content from various sources on a divided screen (Landau, 2015), a description of a patent application solving the problem of viewing electronic illustrated books (Murase, 2017), and a description of a prototype of an e-book for visually impaired readers (Jin et al., 2015).

The technological solutions designed with the thought of visually impaired readers deserve particular consideration. The development of e-publishing created new opportunities to access books and press. Text is being converted to speech or enlarged; the electronic devices are employing the Braille alphabet (Junus \& Booth, 2012). Browsing by terms 'blind' and 'Braille' yields 10 results describing devices designated for the visually impaired users.

Browsing by terms navigation, scrolling, turn, turning yielded around 50 patent applications, which are concerned with various ways of viewing digital content.

The group G06/F17/00 (Digital computing or data processing equipment or methods, specially adapted for specific functions) contains descriptions of 260 applications assigned subgroup G06/F17/21 (Text processing), G06/F17/24 (Editing, e.g. insert / delete), G06/ F17/27 (Automatic analysis, e.g. parsing, orthographic correction). IReader's proposition to use hand-writing in the e-readers is particularly striking (Cheng et al., 2018). Applications featured in this group were also concerned with the use of EPUB format in e-readers, e.g. 
Androids (Li, 2017), and with a solution allowing annotating digital content (Heo, 2016). In total, around 20 applications were concerned with the use and modification of the EPUB format in digital devices.

The subgroup G06F3/01 (Input arrangements or combined input and output arrangements for interaction between user and computer), whose symbol was used to describe 86 applications, includes, among others, a patent application describing an electronic book capable of displaying three-dimensional models (Gonzalez, 2018), or IBM's proposal regarding a display of additional information on the object mentioned in an electronic publication (Ekambaram \& Rakshit, 2018).

Tab. 5. Thematic scope of the patent applications

(taking into account the symbols occurring at least 50 times)

\begin{tabular}{|c|c|c|}
\hline ICP symbol & Number & Description \\
\hline G06F17/30 & 256 & $\begin{array}{l}\text { information retrieval; database structures therefor; file system struc- } \\
\text { tures therefor - organization or management of web site content, } \\
\text { e.g. publishing, maintaining pages or automatic linking }\end{array}$ \\
\hline G06F3/0483 & 196 & interaction with page-structured environments, e.g. book metaphor \\
\hline G06F3/0488 & 120 & $\begin{array}{l}\text { using a touch-screen or digitizer, e.g. input of commands through } \\
\text { traced gestures }\end{array}$ \\
\hline G06Q50/10 & 120 & services \\
\hline G06F3/0484 & 115 & $\begin{array}{l}\text { for the control of specific functions or operations, e.g. selecting or } \\
\text { manipulating an object or an image, setting a parameter value or } \\
\text { selecting a range }\end{array}$ \\
\hline G06F17/21 & 109 & text processing \\
\hline G06F17/24 & 94 & editing, e.g. insert/delete \\
\hline G06Q30/06 & 91 & buying, selling or leasing transactions \\
\hline H04L29/08 & 86 & transmission control procedure, e.g. data link level control procedure \\
\hline G06F3/01 & 86 & $\begin{array}{l}\text { input arrangements or combined input and output arrangements for } \\
\text { interaction between user and computer }\end{array}$ \\
\hline G06F15/02 & 75 & $\begin{array}{l}\text { manually operated with input through keyboard and computation } \\
\text { using a built-in program, e.g. pocket calculators }\end{array}$ \\
\hline G06Q30/02 & 66 & $\begin{array}{l}\text { marketing, e.g. market research and analysis, surveying, promotions, } \\
\text { advertising, buyer profiling, customer management or rewards; price } \\
\text { estimation or determination }\end{array}$ \\
\hline G09B5/06 & 63 & $\begin{array}{l}\text { electrically-operated educational appliances with both visual and } \\
\text { audible presentation of the material to be studied }\end{array}$ \\
\hline G06F3/0481 & 59 & $\begin{array}{l}\text { based on specific properties of the displayed interaction object } \\
\text { or a metaphor-based environment, e.g. interaction with desktop } \\
\text { elements like windows or icons, or assisted by a cursor's changing } \\
\text { behavior or appearance }\end{array}$ \\
\hline G06F17/27 & 56 & automatic analysis, e.g. parsing, orthographic correction \\
\hline H04L29/06 & 50 & characterized by a protocol \\
\hline
\end{tabular}


Descriptions of 120 applications assigned the symbol of subgroup G06Q50/10 (Services) are concerned with various aspects of e-publishing, such as the systems of immediate acquisition (I Sa et al., 2017), methods of creating multi-lingual electronic publications (Yun, 2016), or the means of recommending e-books (Seo, 2016). Generally, more than 30 applications which are concerned specifically with the implementation of a recommended function in electronic devices was found browsing by the term recommend.

Applications from the group G06Q30/00 (Commerce, e.g. shopping or e-commerce) include more than 90 applications from the subgroup G06Q30/06 (Buying, selling or leasing transactions). IReader proposed a system enabling the user to resale e-books (Zou \& He, 2019); Keydo Communication - a system of reviewing digital books using big data (Zou \& He, 2019), and Optim - a method of displaying advertisement that does not disrupt the viewing of the e-book (Sugaya, 2016).

Engineers also work on the application of e-publishing and e-books in advertisement. Browsing the analyzed set by the term 'advertisement' yielded 12 results. Before 2014, such solutions were proposed by Amazon, Microsoft, and Yahoo! (Johnson, 2014). Interestingly, Amazon filed no applications related to advertisement in the period discussed.

The group G09B5/00 (Electrically-operated educational appliances) contained more than 60 applications assigned to the sub-group G09B5/06 (Electrically-operated educational appliances with both visual and audible presentation of the material to be studied). Arbordale Publishing suggests an educational platform transforming e-books into interactive, multilingual publications, using technology supporting reading (German, 2019). Another file is concerned with e-books supporting foreign language learning (Gao, 2015).

More than 130 applications are concerned with transmitting digital information (H04L29/08, H04L29/06). Patent applications propose a system of e-book recommendation based on the technology of data transmission via cloud computing (Yang et al., 2018), a means of sending an e-book as a gift (Landau, 2015), and a system of sharing digital books (Chen, 2018).

\section{Conclusion}

The number of technological solutions concerned with e-publishing has been stable over the last few years. Inventors from East Asia, especially from South Korea and China, are increasingly active, while the European agents are filing less applications. Chinese corporation IReader is particularly active. A slightly lower number of application has been filed by other leading producers on the e-publishing market: Amazon, Rakuten Kobo, and especially Sony and Barnes \& Noble. The number of all agents filing applications should be considered: more than 1000 corporations and individual persons proposed new technological solutions related to e-publishing.

Smaller activity of several companies does not mean that they do no work in the area. Implementation of a given solution might take several years; only now the new inventions of such producers as Barnes \& Noble and Sony do begin to enter the market (Kozlowski, 2018).

The crucial question is which of the proposed solutions will start a new trend in the development of the e-publishing infrastructure. It is likely that majority of the proposed innovations will belong the group of the so-called incremental innovations, i.e., solutions 
which do not cause a break-through in the production technology, but only introduce newer, improved, in the creators' opinion, functions to the already established technologies (Majewska \& Szulczyńska, 2012). In the case of the analyzed group, basing on the IPC symbols, it might be observed that the applicants focus mostly on certain functions facilitating the interaction between the user and the electronic devices. However, applications concerned with e-commerce, and the use of e-publishing in education are as numerous.

\section{References}

Abbas, A., Zhang, L., \& Khan, S. U. (2014). A Literature Review on the State-of-The-Art in Patent Analysis [online]. World Patent Information, 37, 3-13, https://doi.org/10.1016/j.wpi.2013.12.006 Abraham, B. P., Moitra, S. D. (2001). Innovation Assessment Through Patent Analysis. Technovation, 21(4), 245-252, https://doi.org/10.1016/S0166-4972(00)00040-7

BBC (2011). Retail Giant Buys Kobo Ebook Firm [online]. BBC News [16.11.2019], https://www.bbc. com/news/business-15664947

Beavers, A., Johnston, C., Paglia, M., Armstrong, B., Streu, N. S. (2016). Patent Nr US2016041700 (A1) [online]. Espacenet [12.11.20109], https://worldwide.espacenet.com/publicationDetails/biblio?FT=D\&date $=20160211 \& D B=E P O D O C \& l o c a l e=$ en_EP\&CC $=U S \& N R=2016041700 A 1 \& K C=A 1 \& N D=4$

Breitzman, A. F., Mogee, M. E. (2002). The Many Applications of Patent Analysis. Journal of Information Science, 28(3), 187-205, https://doi.org/10.1177/016555150202800302

Breitzman, A., Thomas, P. (2002). Using Patent Citation Analysis to Target/Value M\&A Candidates. Research-Technology Management, 45(5), 28-36, https://doi.org/10.1080/08956308.2002.11671519

Burak, A. (2015). Statystykami patentów można wykazać dowolne tezy [online]. Obserwator Finansowy: Ekonomia, debata, Polska, Świat. [12.11.2019], https://www.obserwatorfinansowy.pl/tematyka/ makroekonomia/statystykami-patentow-mozna-wykazac-dowolne-tezy/

Burke, P. S. (2013). e-Publikacje w InDesign ${ }^{\circ}$ CS6: Projektowanie i tworzenie publikacji cyfrowych dla tabletów, czytników, smartfonów i innych urzadzeń. Warszawa: APN Promise.

Chen, J., Han, F., Yuan, Y., Lei, X., Chen, Y., Lu, J. (2018). Patent Nr CN107608596 (A) [online]. Espacenet [12.11.2019], https://worldwide.espacenet.com/publicationDetails/biblio?FT=D\&date $=20180119 \& D B=E P O D O C \& l o c a l e=$ en_EP \&CC $=C N \& N R=107608596 A \& K C=A \& N D=4$

Chen, X. (2018). Patent Nr CN108462757 (A) [online]. Espacenet [12.11.2019], https://worldwide. espacenet.com/publicationDetails/biblio?FT $=$ D\&date $=20180828 \& D B=E P O D O C \& l o c a l e=e n$ $\mathrm{EP} \& C C=\mathrm{CN} \& \mathrm{NR}=108462757 \mathrm{~A} \& \mathrm{KC}=\mathrm{A} \& \mathrm{ND}=4$

Cheng, C., Tao, H. (2018). Patent Nr CN108959201 (A) [online]. Espacenet [12.11.2019], https:// worldwide.espacenet.com/publicationDetails/biblio?FT $=\mathrm{D} \&$ date $=20181207 \& \mathrm{DB}=\mathrm{EPODOC} \& \mathrm{lo}-$ cale $=$ en $\_$EP\&CC $=C N \& N R=108959201 \mathrm{~A} \& K C=A \& N D=4$

Daim, T. U., Rueda, G., Martin, H., Gerdsri, P. (2006). Forecasting Emerging Technologies: Use of Bibliometrics and Patent Analysis. Technological Forecasting and Social Change, 73(8), 981-1012, https://doi.org/10.1016/j.techfore.2006.04.004

Ekambaram, V., Rakshit, S. K. (2018). Patent Nr US2018107638 (A1) [online]. Espacenet [12.11.2019], https://worldwide.espacenet.com/publicationDetails/biblio?FT $=$ D\&date $=20180419 \& D B=E P O-$ DOC\&locale $=$ en_EP $\& C C=U S \& N R=2018107638 A 1 \& K C=A 1 \& N D=4$

Espacenet (n.d.). Espacenet - Priority Number [online]. Espacenet - European Patent Office [12.11.2019], https://worldwide.espacenet.com/help?locale=en_EP\&method=handleHelpTopic\&topic $=$ prioritynumber

Gao, L. (2015). Patent Nr CN204257022 (U) [online]. Espacenet [12.11.2019], https://worldwide. espacenet.com/publicationDetails/biblio?FT $=$ D\&date $=20150408 \& D B=E P O D O C \& l o c a l e=e n$ $\mathrm{EP} \& \mathrm{CC}=\mathrm{CN} \& \mathrm{NR}=204257022 \mathrm{U} \& \mathrm{KC}=\mathrm{U} \& \mathrm{ND}=4$ 
German, L. B. (2019). Patent Nr US2019196675 (A1) [online]. Espacenet [12.11.2019], https://worldwide.espacenet.com/publicationDetails/biblio?FT $=$ D\&date $=20190627 \& D B=E P O D O C \& l o c a l e-$ $=$ en $\_$EP \&CC $=$US\&NR $=2019196675 \mathrm{~A} 1 \& \mathrm{KC}=\mathrm{A} 1 \& \mathrm{ND}=4$

Gonzalez, D. R. S. (2018). Patent Nr US2018059880 (A1) [online]. Espacenet [12.11.2019], https:// worldwide.espacenet.com/publicationDetails/biblio?FT $=$ D\&date $=20180301 \& D B=E P O D O C \& l o-$ cale $=$ en_EP \&CC $=U S \& N R=2018059880 A 1 \& K C=A 1 \& N D=4$

Griffey, J. (2012). E-Readers Now, E-Readers Forever! Library Technology Reports, 48(3), 14-20.

Gui, B., Ju, Y., Liu, Y. (2019). Mapping Technological Development Using Patent Citation Trees: An Analysis of Bogie Technology. Technology Analysis E Strategic Management, 31(2), 213-226.

Harris, S. (2010). Emergence of the E-book. Nature Photonics, 4(11), 748-749, https://doi.org/10.1038/ nphoton.2010.247

Heo, I. (2016). Patent Nr US2016170591 (A1) [online]. Espacenet [12.11.2019], https://worldwide. espacenet.com/publicationDetails/biblio?FT $=$ D\&date $=20160616 \& D B=E P O D O C \& l o c a l e=e n$ $\mathrm{EP} \& C \mathrm{C}=\mathrm{US} \& \mathrm{NR}=2016170591 \mathrm{~A} 1 \& \mathrm{KC}=\mathrm{A} 1 \& \mathrm{ND}=4$

Herther, N. K. (2008). The Ebook Reader Is Not the Future of Ebooks. Searcher, 16(8), 26-40.

Hicks, D., Breitzman, T., Olivastro, D., Hamilton, K. (2001). The Changing Composition of Innovative Activity in the US - a Portrait Based on Patent Analysis. Research Policy, 30(4), 681-703, https:// doi.org/10.1016/S0048-7333(00)00147-5

I Sa. Y., Kim, D. H., Kim, H. S., Park, B. G. (2017). Patent Nr KR101715814 (B1) [online]. Espacenet [12.11.2019], https://worldwide.espacenet.com/publicationDetails/biblio?FT=D\&date$=20170320 \& D B=E P O D O C \& l o c a l e=e n \_E P \& C C=K R \& N R=101715814 B 1 \& K C=B 1 \& N D=4$

IPC Publication (n.d.). [online]. Międzynarodowa Klasyfikacja Patentowa [14.11.2019], http://mkp. uprp.pl/classifications/ipc/ipcpub/

Jin, H., Wei, C., Peng, P., Zhou, Z. (2015). Patent Nr CN104318821 (A) [online]. Espacenet [12.11.2019], https://worldwide.espacenet.com/publicationDetails/biblio?FT $=$ D\&date $=20150128 \& D B=E P O-$ DOC\&locale $=$ en_EP\&CC $=C N \& N R=104318821 \mathrm{~A} \& K C=\mathrm{A} \& N D=4$

Johnson, B. (2014). Would I Read an Ad-Supported Ebook? Probably. Computers in Libraries, 34(4), $10-14$.

Jun, S., Sung Park, S. (2013). Examining Technological Innovation of Apple Using Patent Analysis. Industrial Management \& Data Systems, 113(6), 890-907, https://doi.org/10.1108/IMDS-012013-0032

Junus, S. G. R., Booth, C. (2012). E-books and E-readers for Users with Print Disabilities. Library Technology Reports, 48(7), 22-28.

Kang, B. (2015). The Innovation Process of Huawei and ZTE: Patent Data Analysis. China Economic Review, 36, 378-393, https://doi.org/10.1016/j.chieco.2014.12.003

Kozlowski, M. (2018, styczeń 2). E-Reader Trends and Statistics for 2018 [online]. Good e-Reader. [17.11.2019], https://goodereader.com/blog/electronic-readers/e-reader-trends-and-statisticsfor-2018

Landau, B. (2015). Patent Nr US2015234786 (A1) [online]. Espacenet [12.11.2019], https://worldwide.espacenet.com/publicationDetails/biblio?FT $=$ D\&date $=20150820 \& D B=E P O D O C \& l o c a-$ le $=$ en_EP $\& C C=U S \& N R=2015234786 A 1 \& K C=A 1 \& N D=4$

Landau, B. (2015). Patent Nr US2015317050 (A1) [online]. Espacenet [12.11.2019], https://worldwide.espacenet.com/publicationDetails/biblio?FT $=$ D\&date $=20151105 \& D B=E P O D O C \& l o c a-$ le $=$ en_EP \&CC $=U S \& N R=2015317050 A 1 \& K C=A 1 \& N D=4$

Lens (n.d.). About The Lens [online]. The Lens - Free Open Patent and Scholarly Search [12.11.2019], https://about.lens.org/

Li, C. (2017). Patent Nr CN107220221 (A) [online]. Espacenet [12.11.2019], https://worldwide.espacenet.com/publicationDetails/biblio?FT $=$ D \&date $=20170929 \& D B=E P O D O C \& l o c a l e=e n \_E P \& C$ $\mathrm{C}=\mathrm{CN} \& \mathrm{NR}=107220221 \mathrm{~A} \& \mathrm{KC}=\mathrm{A} \& \mathrm{ND}=4$ 
Majewska, M., Szulczyńska, U. (2012). Innowacje przyrostowe jako źródło postępu technologicznego gospodarce opartej na wiedzy. Zeszyty Naukowe Uniwersytetu Szczecińskiego. Ekonomiczne Problemy Ustug, 87, 1, 101-109.

Manley, L., Holley, R. P. (2012). History of the Ebook: The Changing Face of Books. Technical Services Quarterly, 29(4), 292-311, https://doi.org/10.1080/07317131.2012.705731

Martínez, C., Rama, R. (2012). Home or Next Door? Patenting by European Food and Beverage Multinationals. Technology Analysis \& Strategic Management, 24(7), 647-661.

Meyer, M., Utecht, J. T., Goloubeva, T. (2003). Free Patent Information as a Resource for Policy Analysis. World Patent Information, 25(3), 223.

Milliot, J. (2018). E-book Sales Fell 10\% in 2017 [online]. Publishers Weekly, [12.11.2019], https:// www.publishersweekly.com/pw/by-topic/digital/content-and-e-books/article/76706-e-book-sales-fell-10-in-2017.html

Montecchi, T., Russo, D., Liu, Y. (2013). Searching in Cooperative Patent Classification: Comparison Between Keyword and Concept-Based Search. Advanced Engineering Informatics, 27(3), 335-345, https://doi.org/10.1016/j.aei.2013.02.002

Murase, S. (2017). Patent Nr US2017038931 (A1) [online]. Espacenet [12.11.2019], https://worldwide.espacenet.com/publicationDetails $/$ biblio $? F T=D \&$ date $=20170209 \& D B=E P O D O C \& l o c a-$ le $=$ en_EP \&CC $=$ US \&NR $=2017038931 \mathrm{~A} 1 \& \mathrm{KC}=\mathrm{A} 1 \& \mathrm{ND}=4$

Nam, K. D. (2019). Patent Nr KR101951757 (B1) [online]. Espacenet [12.11.2019], https://worldwide. espacenet.com/publicationDetails/biblio?FT $=$ D\&date $=20190225 \& D B=E P O D O C \& l o c a l e=e n$ $\mathrm{EP} \& \mathrm{CC}=\mathrm{KR} \& \mathrm{NR}=101951757 \mathrm{~B} 1 \& \mathrm{KC}=\mathrm{B} 1 \& \mathrm{ND}=4$

Nauka w Polsce (n.d.). Wiceprezes UP RP wyjaśnia, dlaczego na patent czeka się średnio 3,6 roku [online]. Nauka w Polsce [17.11.2019], http://naukawpolsce.pap.pl/aktualnosci/news\%2C412791\%2Cwiceprezes-up-rp-wyjasnia-dlaczego-na-patent-czeka-sie-srednio-36-roku.html

Nikzad, R. (2014). Canadian Worldwide Patent Activity: An Industrial Level Analysis. World Patent Information, 38, 12-18, https://doi.org/10.1016/j.wpi.2014.03.001

Orduna-Malea, E., Thelwall, M., Kousha, K. (2017). Web Citations in Patents: Evidence of Technological Impact? Journal of the Association for Information Science E Technology, 68(8), 1967-1974.

Parker, N., Landau, B. (2016). Patent Nr US2016202868 (A1) [online]. Espacenet [12.11.2019], https:// worldwide.espacenet.com/publicationDetails/biblio?FT $=\mathrm{D} \&$ date $=20160714 \& \mathrm{DB}=\mathrm{EPODOC} \& \mathrm{lo}-$ cale $=$ en_EP $\& C C=U S \& N R=2016202868 \mathrm{~A} 1 \& \mathrm{KC}=\mathrm{A} 1 \& \mathrm{ND}=4$

Redl, G., Bogin, L., Parczewski, R. (2016). Jak skutecznie patentować. Warszawa: Narodowe Centrum Badań i Rozwoju.

Seo, Y. T. (2016). Patent Nr KR20160129684 (A) [online]. Espacenet [12.11.2019], https://worldwide. espacenet.com/publicationDetails/biblio?FT $=$ D\&date $=20161109 \& D B=E P O D O C \& l o c a l e=e n$ $E P \& C C=K R \& N R=20160129684 A \& K C=A \& N D=4$

Springer, R. (2017). The State of Ebooks 2017 [online]. EContent Magazine, [16.11.2019], http://www. econtentmag.com/Articles/Editorial/Feature/The-State-of-Ebooks-2017-115709.htm

Sugaya, S. (2016). Patent Nr JP2016184246 (A) [online]. Espacenet [12.11.2019], https://worldwide. espacenet.com/publicationDetails/biblio?FT $=$ D\&date $=20161020 \& D B=E P O D O C \& l o c a l e=e n$ $\mathrm{EP} \& C C=\mathrm{JP} \& N R=2016184246 \mathrm{~A} \& \mathrm{KC}=\mathrm{A} \& \mathrm{ND}=4$

Śnieżko, A. (n.d.). Jak chronić wynalazki w Polsce, w Europie i na świecie Podstawowe pojęcia i procedury [online]. WTS Patent Attorneys, [16.11.2019], http://wtspatent.pl/wp-content/uploads/2014/05/pl1.pdf

Trappey, C. V., Wu, H.-Y., Taghaboni-Dutta, F., Trappey, A. J. C. (2011). Using Patent Data for Technology Forecasting: China RFID Patent Analysis. Advanced Engineering Informatics, 25(1), 53-64, https://doi.org/10.1016/j.aei.2010.05.007

UPRP (n.d.-a) Czym jest patent na wynalazek i prawo ochronne na wzór użytkowy? [online]. Urząd Patentowy Rzeczypospolitej Polskiej [16.11.2019], https://uprp.pl/czym-jest-patent-na-wynalazeki-prawo-ochronne-na-wzor-uzytkowy/Lead05,150,1696,4,index,pl,text/ 
UPRP (n.d.-b). Informacje podstawowe [online]. Urząd Patentowy Rzeczypospolitej Polskiej, [23.11.2019], https://uprp.pl/podstawowe-informacje-o-ochronie-prawnej-wynalazkow-i-wzorowuzytkowych/Lead05,23,1692,4,index,pl,text/

UPRP (n.d.-c). Procedura krajowa [online]. Urząd Patentowy Rzeczypospolitej Polskiej [16.11.2019], https://uprp.pl/procedura-krajowa/Lead05,24,1708,4,index,pl,text/

UPRP (2012). Wskazówki dla użytkowników MKP [online]. Urząd Patentowy Rzeczpospolitej Polskiej [16.11.2019], https://www.uprp.pl/uprp/redir.jsp?place=GalleryStats\&id=64545

Vandeberg, R. L. J., Boon, W. P. C. (2009). Anticipating Emerging Genomics Technologies: The Role of Patents and Publication for Research and Policy Strategies. Genomics, Society \& Policy, 5(2), 1-21.

Xie, Z., \& Miyazaki, K. (2013). Evaluating the Effectiveness of Keyword Search Strategy for Patent Identification. World Patent Information, 35(1), 20-30.

Yang, S., Wang, S., Zhang, H. (2018). Patent Nr CN108228668 (A) [online]. Espacenet [12.11.2019], https://worldwide.espacenet.com/publicationDetails/biblio?FT $=\mathrm{D} \&$ date $=20180629 \& \mathrm{DB}=\mathrm{EPO}-$ DOC\&locale $=$ en_EP\&CC $=C N \& N R=108228668 A \& K C=A \& N D=4$

Yun, K. O. (2016). Patent Nr KR20160140527 (A) [online]. Espacenet [12.11.2019], https://worldwide. espacenet.com/publicationDetails/biblio?FT $=$ D\&date $=20161207 \& D B=E P O D O C \& l o c a l e=e n$ $\mathrm{EP} \& \mathrm{CC}=\mathrm{KR} \& \mathrm{NR}=20160140527 \mathrm{~A} \& \mathrm{KC}=\mathrm{A} \& \mathrm{ND}=4$

Zou, Y., He, L. (2019). Patent Nr CN109389470 (A) [online]. Espacenet [12.11.2019], https://worldwide.espacenet.com/publicationDetails/biblio?FT $=$ D\&date $=20190226 \& D B=E P O D O C \& l o c a l e-$ $=$ en_EP $\& C C=C N \& N R=109389470 A \& K C=A \& N D=4$

\title{
Wybrane aspekty rynku publikacji elektronicznych w świetle zgłoszeń patentowych w latach 2014-2018
}

\begin{abstract}
Abstrakt
Cel/Teza: W artykule dokonano analizy zgłoszeń patentowych dotyczących publikacji elektronicznych. Celem badań była odpowiedź na pytanie, jak w latach 2014-2018 kształtowała się liczba wniosków patentowych, z jakich krajów pochodziły firmy zgłaszające wynalazki oraz jakie firmy były najbardziej aktywne na tym polu. Na podstawie analizy symboli Międzynarodowej Klasyfikacji Patentowej starano się także wyodrębnić pewne kluczowe zagadnienia, nad którymi pracują wynalazcy. Koncepcja/Metody badań: Źródłem analizy były dane z bazy Lens.org obejmujące lata 2014-2018. Łącznie zidentyfikowano 1733 opublikowanych wniosków, dotyczących publikacji elektronicznych oraz urządzeń zapewniających do nich dostęp.

Wyniki i wnioski: Zwraca uwagę duża aktywność chińskich i koreańskich wynalazców oraz niska liczba zgłoszeń patentowych europejskich firm. Wnioskodawcy koncentrują się głównie na pewnych funkcjach ułatwiających interakcję użytkownika z urządzeniami cyfrowymi, ale stosunkowo liczne są także zgłoszenia wynalazków związanych z handlem elektronicznym czy wykorzystaniem publikacji elektronicznych do celów edukacyjnych.

Oryginalność/Wartość poznawcza: Analiza zgłoszeń patentowych może być pomocna w identyfikowaniu określonych zjawisk zachodzących obszarze technologii informacyjnych. Wskazuje zarówno kierunki prac badawczych, jak i kraje i podmioty, które odgrywają wiodącą rolę w rozwoju szeroko rozumianego obszaru publikacji elektronicznych.
\end{abstract}

\section{Słowa kluczowe}

Ebooki. Książki elektroniczne. Patenty. Wydawnictwa elektroniczne. 


\begin{abstract}
ADAM JACHIMCZYK PhD is Assistant Professor at the Department of Bibliography and Documentation at the Faculty of Journalism, Information and Book Studies at University of Warsaw. His research interests encompass the application of information technology in information activities. His publications include: Internetowe zasoby bibliograficzne instytutów badawczych oraz jednostek Polskiej Akademii Nauk (2016). In: J. Franke i J. Woźniak-Kasperek (red.) Bibliografia: historia, teoria, praktyka: praca zbiorowa. Warszawa: SBP; with M. and Z. Chrapek: Web directories: selected features and their impact on directory quality (2016). Program-Electronic Library and Information Systems, vol. 50 no 3; and Otwarte dane badawcze. Casus polskich instytutów badawczych (2015). Zagadnienia Naukoznawstwa, nr 4.
\end{abstract}

Contact to the Author

a.jachimczyk@uw.edu.pl

Department of Bibliography and Documentation

Faculty of Journalism, Information and Book Studies

University of Warsaw

Nowy Świat 69

00-046 Warsaw 